\title{
A PORTFÓLIÓ \\ TANÁRKÉPZÉSBEN ÉS A KÖZOKTATÁSBAN TÖRTÉNŐ ALKALMAZÁSÁNAK LEHETŐSÉGE EGY VIZSGÁLAT TÜKRÉBEN
}

\author{
HANÁK ZSUZSANNA
}

\author{
az Eszterházy Károly Főiskola TKTK \\ föiskolai tanára \\ hanak@ektf.hu
}

Tanulmányunkban a portfolió tanárképzésben történö alkalmazásának eddigi tapasztalatait kívánjuk elemezni, az eredményeket bemutatni. Munkánk során a pedagógusok továbbképzési tapasztalatain túl a módszer közoktatásban történö használhatóságát is vizsgáljuk.

\section{Bevezető, a vizsgálat előzményei}

A ,portfólió” szó Amerikából került napjaink modern világába, aktát, mappát, irattartót jelent, pontosabban olyan irattartót, amibe fontos dokumentumok kerülnek. A hazai szakirodalom (Falus és Kimmel, 2003) többféle megközelítésről tesz említést. A különböző definíciók úgy határozzák meg a portfóliót, mint olyan dokumentumgyüjteményt, amely a tanuló munkáit hivatott bemutatni, vagy mint olyan gyüjteményt, amely a diák adott időszak alatti fejlődéséröl ad számot, esetleg mind a két értelmezést tartalmazzák vagy megengedik.

A portfólió gyakorlatban használatos típusainak megnevezése különbözö, a nemzetközi szakirodalmakban is ez látható.

Barett (2002) munkaportfólióról, bemutató portfólióról, és értékelési portfólióról beszél. E felosztásban egyfajta építkezést láthatunk. A munkaportfólió segítségével a tanár és a diák rendszeresen megvitatja a diák elörehaladását egy adott tárgyból vagy egy adott projektben. Egy tanuló munkája egy tananyagról tartalmazhat már elkészült munkákat, de olyanokat is, amelyek befejezetlenek. Egyes elemeit értékelési portfólióban és bemutató portfólióban is felhasználhatja. E portfóliótípus egyéni differenciálásra is alkalmas. A munkaportfólióból a bemutató portfólióba már csak a diák legjobb/legfontosabb munkái kerülnek. Ezeket a tanuló válogatja össze azokból a dokumentumokból, amelyek véleménye szerint a legjobban bemutatják őt és elért eredményeit. Az értékelési portfólió alternatív osztályozást, értékelést szolgál. Lényege, hogy a tanár a hagyományos osztályozással szemben a diák teljesítményét holisztikusan, az összes jellemző dokumentum segítségével ítélhesse meg. 
Tehát a munkaportfólió tartalma lehet még el nem készült munka dokumentuma, de lehet befejezett anyag is. A bemutató portfólióba csak a legjobb, legfontosabb tanulói munkák dokumentumai kerülnek, nem minden. Az értékelési portfólióba pedig azok a dokumentumok, melyeket a tanár értékelni fog. Ehhez világos értékelési szempontrendszer kell, hogy rendelkezésére álljon, ezt a tanulónak ismerni kell, mivel elképzelhető, hogy a bemutató portfólióba összegyüjtött dokumentumok nem fedik le a követelményeket. Az értékelési portfólióba azok a munkák kerülnek, amelyeket a tanterv, tematika kimeneti követelményként elöír.

Oswald Inglin (2006) a tanítási órákon történő alkalmazási módokat foglalta rendszerbe. Szerinte öt modelltípus alakult ki a gyakorlatban (1.ábra):

- Parallel modell: a tanulók időtől és témától függetlenül egy tanár irányítása alatt végzik a munkát. Gyakorlatilag hagyományos tanóra zajlik, és ezzel párhuzamosan a hagyományos óra anyagai kerülnek a portfólióba.

- Fázis modell: portfóliót a tanítási folyamat csak egyes fázisában alkalmazzák, pl. egy témakör összefoglalásánál.

- Centripetális modell: a tanár a tanulók portfólióiból integrál elemeket a tanítási óra bizonyos részeibe. A fix pontok adják, az ún. „portfólió órákat” (,work in progress" órákat).

- Centrifuga modell: az órákon készült dokumentumok egy része bekerül az egyes tanulók portfólió anyagába.

- Egység modell: az egész tanítási óra a portfólió készítéssel és értékeléssel telik el az egész tanév során.

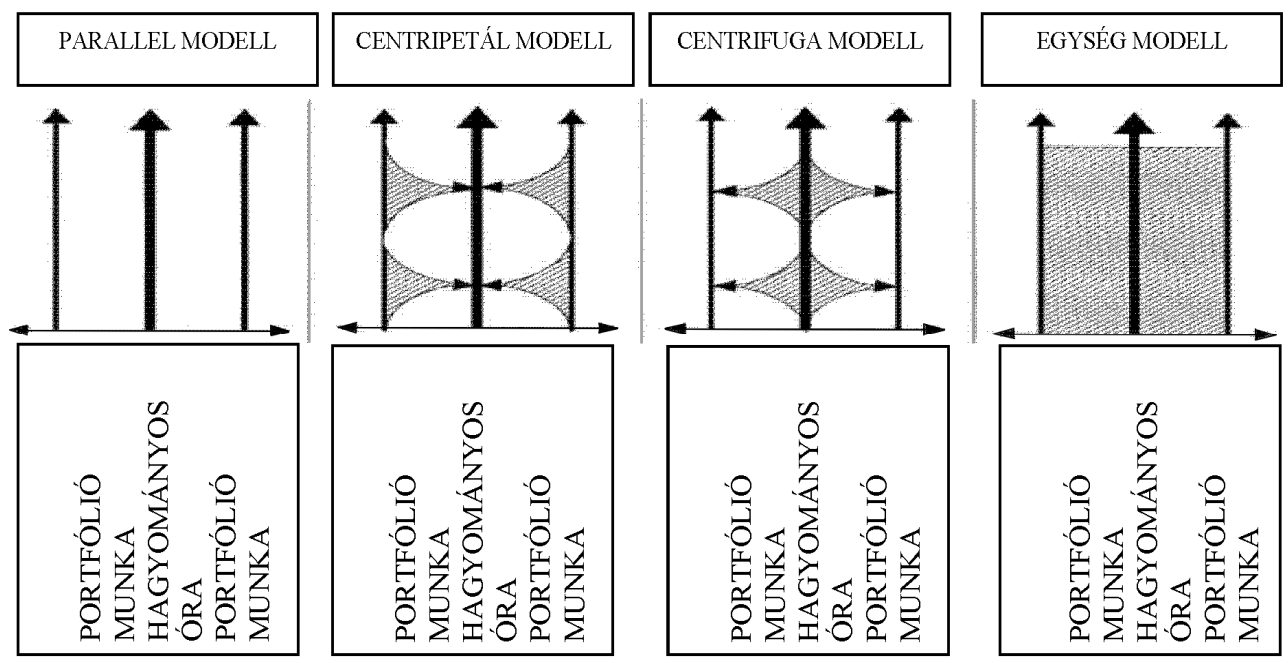

1. ábra: A portfólió tanórákon történő alkalmazási módjai Oswald Inglin (2006) szerint 
Tehát ebben a modellben a hangsúly nem a portfóliótípusok tartalmi építkezésén van (munkaportfólió, bemutató portfólió, értékelési portfólió), hanem a tanórai konkrét felhasználhatóságot foglalja össze, természetesen az adott félévre, tanévre kiterjesztve azt. Világosan látható, hogy a portfólió munka a hagyományos tanóra munkáival összhangba hozható, a tanár döntése, melyiket alkalmazza.

A portfólió a felsőoktatásban - véleményünk szerint - jól alkalmazható. Kollégáimmal a felsőoktatásban kipróbáltuk a fázis és a centrifuga modelltípust, valamint a bemutató portfóliót. A fázis típusú modellt azért választottuk, mert olyan modellt kerestünk, amely megengedi, hogy hagyományos órákat tartva, bizonyos témák esetén portfóliót használhassunk. Mivel a föiskolán egy-egy kurzushoz (tantárgyhoz) előadás, szeminárium, gyakorlat is tartozhat, a fázis típusú modell jónak tűnt. Az előadáson és szemináriumon hagyományos órákat tartottunk, a gyakorlaton portfóliót készítettek a hallgatók. Ugyanakkor egy-egy tárgy, pl. csak szemináriumi feldolgozást kapott, ez esetben a centrifuga modelltípus tünt megfelelőnek, mivel az órán készült dokumentumok egy része kerülhetett be a gyüjteménybe, ezzel otthon a hallgatók tovább dolgozhattak. Például az egyéni bánásmódot, differenciált fejlesztést igénylő tanulók definiálását, jellemzőinek feldolgozását kooperatív kiscsoportok feldolgozták, ezt követően egyénileg szakirodalmak segítségével a portfóliójukban rögzítették a fejlesztés lehetőségeit, fejlesztési tervet készítettek.

A képzés zárásánál a bemutató portfóliót választottuk. E portfólió prezentálása volt a záróvizsga egy része. Azért nem az értékelési portfólióra esett a választásunk, mivel a hallgató legjobb munkáit akartuk látni, alternatív osztályzásra nem volt lehetőségünk, a kimeneti követelményeket a záróvizsga további részében ellenőrizni tudtuk.

\section{Vizsgálati tapasztalatok a portfólió tanárképzésben és a közoktatásban történő alkalmazásáról}

A vizsgálat célja a portfólió kiterjesztése a pedagógusképzésre, az eddigi tapasztalatok felmérése, feldolgozása, a módszer sajátosságainak elemzése, további teendők megfogalmazása, valamint a közoktatásban történő alkalmazhatóság feltárása volt.

A vizsgálati mintát a Fejlesztö-differenciáló szakpedagógus képzésben, a 2009ben és 2010-ben végzett, másoddiplomás hallgatók képezték, akik korábbi diplomájukat hagyományos módszerek alkalmazásával szerezték, a portfóliót most új módszerként használták. A „Fejlesztő-differenciáló szakpedagógia” szakirányú továbbképzés öt féléve alatt az első (alapozó) féléven kívül, minden gyakorlati jegyet adó tantárgynál portfóliókkal dolgoztunk. A képzés portfólió alapú záró dolgozattal fejeződött be, melynek prezentálása révén adtak számot a hallgatók szakmai fejlödésükről. A tanulmányi idő alatt megszerzett kompetenciák bizonyító alapjait adták a portfólió dokumentumai. A felmért csoport óvodapedagógusokból, tanítókból, általános és középiskolai tanárokból, szociálpedagógusokból, gyógypedagógusokból 
tevődött össze (1. táblázat), összesen 90 fő. A vizsgálati minta átlag életkora 43 év, a többségük aktívan a pedagógus pályán dolgozik (2. táblázat). A megkérdezettek 45\%-a több mint 20 éve van a pedagógus pályán, pályakezdőnek csupán 5\% számít. A legtöbben több éves pedagógiai tapasztalattal rendelkeznek (3. táblázat).

1. táblázat: A vizsgálati minta végzettség szerint

\begin{tabular}{|l|c|}
\hline Óvodapedagógus & $27 \%$ \\
\hline Tanítónő & $26 \%$ \\
\hline Általános iskolai tanár & $25 \%$ \\
\hline Középiskolai tanár & $10 \%$ \\
\hline Gyógypedagógus & $10 \%$ \\
\hline Szociálpedagógus & $2 \%$ \\
\hline
\end{tabular}

\section{2. táblázat:}

\begin{tabular}{|l|c|}
\hline Jelenleg aktívan a pedagógus pályán dolgozik: & $97 \%$ \\
\hline Nem pedagógusi állásban van: & $3 \%$ \\
\hline
\end{tabular}

3. táblázat: A vizsgálati minta jelenlegi munkakör szerint

\begin{tabular}{|l|c|}
\hline Pályakezdő: & $5 \%$ \\
\hline $3-5$ év: & $3 \%$ \\
\hline $5-10$ év: & $18 \%$ \\
\hline $11-15$ év: & $15 \%$ \\
\hline $16-20$ év: & $14 \%$ \\
\hline Több mint 20 év: & $45 \%$ \\
\hline
\end{tabular}

A vizsgálatban alkalmazott módszerek a következők voltak:

1. Dokumentumelemzés: az elkészített portfóliók értékelése

2. Kérdőív: a portfólió közoktatásban történő alkalmazhatóságáról

A vizsgálat menete (lebonyolítása) a következő lépésekből állt: az elméleti órákon a hallgatók megismerték a szakmai terminusokat, definíciókat, módszereket, méréseket (pl.: pedagógiai diagnosztika, preventív-korrektív fejlesztés stb.), majd a szemináriumokon ezek gyakorlati alkalmazása volt a téma, ekkor centrifuga modelltípusú portfóliót alkalmaztunk. Ezt követően a gyakorlatban elvégezték a szemináriumokon megbeszélt feladatokat (pl.: megfigyelések, mérések, fejlesztések stb.), és ezek eredményeikkel szupervízión vettek részt (kiscsoportban, ill. egyénileg). Szuperví- 
ziókra fázis modelltípusú portfólióval jöttek. A képzés végére kialakult a bemutató portfólió, mely az összes jellemző dokumentumot magába foglalta, és ennek segítségével a hallgató saját szakmai fejlődéséről be tudott számolni. Ezt követően a záróvizsgák után az elkészült portfóliók eredményeit elemeztük, illetve a pedagógusok véleményét mértük fel a portfólió közoktatásban történő alkalmazhatóságával kapcsolatban. Úgy gondoljuk, a pedagógusok portfóliókkal összefüggő saját tapasztalatai és a mindennapi közoktatásban végzett munkájuk alapján meg tudják ítélni a közoktatási alkalmazás lehetőségét. A portfólióval összefüggő ismeret, szempontsor a hallgatók számára adott volt a képzés során.

A vizsgálat eredményei: a bemutató portfóliókat tartalmi mutatók, valamint formai megjelenítés alapján elemeztük. Ezt egészítette ki a prezentáció, azaz a portfólióban dokumentált anyagok szóbeli bemutatása. Ezt tartalom, forma és előadásmód alapján értékeltük. Az elkészített portfóliók és prezentálásuk értékelésével kapcsolatban a következőket állapítottuk meg (4. táblázat):

4. táblázat: A portfóliók és prezentálásuk eredményei

\begin{tabular}{|l|c|}
\hline \multicolumn{2}{|c|}{ PORTFÓLIÓ ÉRTÉKELÉSE } \\
\hline \multicolumn{1}{|c|}{ Tartalmi mutatók } & A hallgatók által elért \%-os eredmény \\
\hline $\begin{array}{l}\text { Bevezetö } \\
\text { (max. 5 pont) }\end{array}$ & $89 \%$ \\
\hline $\begin{array}{l}\text { Anamnézis } \\
\text { (max. 5 pont) }\end{array}$ & $84 \%$ \\
\hline $\begin{array}{l}\text { Exploráció } \\
\text { (max. 5 pont) }\end{array}$ & $91 \%$ \\
\hline $\begin{array}{l}\text { Fejlettségi szintmérés } \\
\text { (max. 5 pont) }\end{array}$ & $90 \%$ \\
\hline $\begin{array}{l}\text { Fejlesztési terv } \\
\text { (max. 5 pont) }\end{array}$ & $82 \%$ \\
\hline $\begin{array}{l}\text { Pedagógiai jellemzés } \\
\text { (max. 5 pont) }\end{array}$ & $86 \%$ \\
\hline $\begin{array}{l}\text { Iskolai fejlódés nyomon követése } \\
\text { (max.5 pont) }\end{array}$ & $86 \%$ \\
\hline $\begin{array}{l}\text { Iskolai fejlesztések } \\
\text { (max. 5 pont) }\end{array}$ & $86 \%$ \\
\hline $\begin{array}{l}\text { Zárszó } \\
\text { (max. 2 pont) }\end{array}$ & $80 \%$ \\
\hline $\begin{array}{l}\text { Szakirodalmi gyüjtemény } \\
\text { (max. 5 pont) }\end{array}$ & $78 \%$ \\
\hline
\end{tabular}




\begin{tabular}{|l|c|}
\hline \multicolumn{2}{|c|}{ PORTFÓLIÓ ÉRTÉKELÉSE } \\
\hline \multicolumn{1}{|c|}{ Tartalmi mutatók } & A hallgatók által elért \%-os eredmény \\
\hline $\begin{array}{l}\text { Formai megjelenítés } \\
\text { (max. 3 pont) }\end{array}$ & $80 \%$ \\
\hline \multicolumn{2}{|c|}{ PREZENTÁCIÓ ÉRTÉKELÉSE } \\
\hline $\begin{array}{l}\text { Tartalom } \\
\text { (max. 20 pont) }\end{array}$ & $87 \%$ \\
\hline $\begin{array}{l}\text { Forma } \\
\text { (max. 15 pont) }\end{array}$ & $89 \%$ \\
\hline $\begin{array}{l}\text { Előadásmód } \\
\text { (max. 15 pont) }\end{array}$ & $78 \%$ \\
\hline
\end{tabular}

A portfóliók elemzésénél megállapítható, hogy a hallgatók az előre megadott szempontrendszer alapján, de saját személyiségük, érdeklődési körük, előzetes, ill. a képzés alatt megszerzett szaktudás alapján alakították ki azt.

A bevezetőkben saját eddigi szakmai életutakról írnak, szakmai hitvallást fogalmaznak meg, bemutatják munkahelyüket és a tanítványaikat. Az anamnézist és az explorációt klasszikus kérdőívek, megfigyelési szempontok alapján interjú, illetve megfigyelés módszerével végezték el. Az értékelésben kiemelték a gyermek fejlődésében látható rizikófaktorokat, a korai szocializációs ártalmakat és az MCD-re utaló jeleket. A fejlettségi szint mérésénél elsősorban a képzés során megtanult pedagógiai vizsgálatokat végezték el (pl. iskolaérettségi vizsgálat, kiegészítő vizsgálatok), de többen felhasználták a már meglévő egyéb végzettségükkel összefüggő kompetenciáikat is (pl. gyógypedagógusok). A fejlesztési terveket megadott szempontok alapján állították össze, ezek összhangban vannak a mérések során feltárt részképesség problémákkal.

Az eddig leírt portfólió dokumentumok iskolát kezdeni kívánó, ill. kisiskolás gyermekek anyagait tartalmazták. A pedagógiai jellemzések, az iskolai fejlődés nyomonkövetése, valamint az iskolai fejlesztések már „,nagyobb“ tanulókra vonatkoztak. A megfigyelések, vizsgálatok, fejlesztések az egyéni bánásmód, differenciált képességfejlesztés irányát mutatják, ami kiemelt célja volt a képzésnek.

A zárszóban hallgatóink önértékelést végeztek, valamint a további szakmai terveiket foglalták össze. A szakirodalmi gyüjteményekben a mindennapi gyakorlatban felhasználható irodalmakat (szakkönyvek, munkalapok, fejlesztő játékok katalógusa) gyüjtötték össze.

Az értékelés számszaki eredményei igen jók, valószínüleg ezekhez az eredményekhez hozzájárult a portfólió alkalmazása is. A szakirodalmi gyüjtemény elkészítése fejleszthető, ezzel növelhető az elméleti háttér ismerete. 
A prezentációkat elemezve megállapíthatjuk, hogy a tartalom és a formai megjelenítés jó, de az előadásmód, a szakmai terminusok helyes használata, a stílus javítható.

Vizsgálatunkban elemeztük a pedagógusok véleményét a portfólió közoktatásban történő alkalmazhatóságáról. Mint ahogyan azt már írtuk, úgy gondoljuk, hogy a pedagógusok portfóliókkal összefüggő saját tapasztalataik és a mindennapi közoktatásban végzett munkájuk alapján meg tudják ítélni a közoktatási alkalmazás lehetöségét.

A hallgatók 30 állításról adtak véleményt ötfokú skálán való bejelöléssel a következö fokozatokban (1 nem ért egyet; 2 inkább nem; 3 részben; 4 inkább igen; 5 igen, teljesen egyetért). A következő táblázat (5. táblázat) a 30 állításra adott értékek átlagát mutatja be:

5. táblázat: A pedagógusok véleménye a portfólió közoktatásban történő alkalmazhatóságáról

\begin{tabular}{|c|l|c|}
\hline Rangsor & \multicolumn{1}{|c|}{ Állitás } & Vélemények \\
\hline 1. & Növeli a tanulók önállóságát & 4,47 \\
\hline 2. & Eredménye gyakran az, hogy a tanulók büszkék munkájukra & 4,47 \\
\hline 3. & Hasznosnak tartom a tanulók számára & 4,16 \\
\hline 4. & Más óravezetést igényel & 4,13 \\
\hline 5. & Tanuló-centrikus, az egyénre koncentrál & 4,05 \\
\hline 6. & Növeli a tanulók felelősségérzetét & 3,95 \\
\hline 7. & Több kooperációt kíván a tanár-diák között & 3,89 \\
\hline 8. & Növeli a tanulók önbizalmát & 3,87 \\
\hline 9. & Megváltoztatja tanári szerepemet & 3,87 \\
\hline 10. & Idöigényes & 3,79 \\
\hline 11. & Növeli a tanulók tanulási kedvét & 3,76 \\
\hline 12. & Csökkenti a stresszt a gyengébb tanulóknál & 3,68 \\
\hline 13. & Sok terhet ró a tanárra & 3,55 \\
\hline 14. & Nem minden tananyagnál, tantárgynál alkalmazható & 3,45 \\
\hline 15. & Nem teljesen az órai munkát tükrözi & 3,39 \\
\hline 16. & Sok tanárkollégának is fenntartásai vannak e módszernél & 3,39 \\
\hline 17. & Nem minden korosztálynál alkalmazható & 3,37 \\
\hline 18. & A tantárgyi követelmények nem erről szólnak & 3,26 \\
\hline 19. & Nem elterjedt, elfogadott módszer & 3,21 \\
\hline 20. & A tantervbe nehezen illeszthető be & 3,16 \\
\hline 21. & Sok terhet ró a tanulókra & 3,11 \\
\hline & & \\
\hline
\end{tabular}




\begin{tabular}{|c|l|c|}
\hline Rangsor & \multicolumn{1}{|c|}{ Állitás } & Vélemények \\
\hline 22. & Növeli a tanulók közti konkurenciát & 3,03 \\
\hline 23. & A hitelessége sem garantált (értékelés, saját-idegen munka & 3,03 \\
\hline 24. & A szülök sem fogadják el teljesen & 2,89 \\
\hline 25. & Nem a tényanyagra helyezi a hangsúlyt & 2,87 \\
\hline 26. & Csökkenti a tanár terhelését & 2,79 \\
\hline 27. & Nincs benne sok új elem & 2,71 \\
\hline 28. & Nehezen értékelhető & 2,68 \\
\hline 29. & Csak a szakképzésben használható & 2,34 \\
\hline 30. & Csak a felnőtt képzésben alkalmazható & 2,34 \\
\hline
\end{tabular}

A 4,00 átlag feletti eredményeket tekinthetjük úgy, hogy a vizsgálati minta egyetért az állítással, az első öt ranghelyen végzett állítást tovább elemeztük. Mivel a résztvevők a portfóliók önállóság növelő szerepével értenek egyet a legnagyobb mértékben (teljesen egyetért 50\%, inkább egyetért 49\%), így ez került az első ranghelyre. Egyértelmüen vélekednek arról, hogy a portfólió produktumai büszkeséggel töltik el a tanulókat (teljesen egyetért 50\%, inkább egyetért 49\%), nemleges válasz nem született. A harmadik helyre a portfolió tanulók számára való hasznossága került (teljesen egyetért 24\%, inkább egyetért 68\%), e tény is a módszer alkalmazása mellett szól. Csak néhány századdal marad le ettől a módszer gyakorlati alkalmazhatóságának értékelése (teljesen egyetért $37 \%$, inkább egyetért $45 \%$ ). A portfólió tanulócentrikussága igen jó véleményt kapott a pedagógusoktól (teljesen egyetért $34 \%$, inkább egyetért $42 \%$ )

A 2,5 átlageredményeknél kevesebb pontot kapott állításoknál a hallgatók az állítással inkább nem értenek egyet, tehát a csak szakképzésben és a felnőttképzésben való alkalmazást elutasítják.

A vizsgálati mintánkban felmért három populáció (óvodapedagógus, tanító, tanár) vélekedésében kiemelkedő eltérést nem találtunk, a három minta adatai között nincs szignifikáns különbség.

\section{Következtetések}

Munkánk célja volt a portfólió kiterjesztése a pedagógusképzésre, az eddigi tapasztalatok felmérése, feldolgozása, a módszer sajátosságainak elemzése, további teendők megfogalmazása, valamint a közoktatásban történő alkalmazhatóság feltárása.

A portfólió módszer a felsőoktatásban jól használható. A módszert kipróbáló pedagógusok a közoktatásban is felhasználható, hatékony módszernek vélik saját élményeik alapján. A portfólió segíti a hallgatók önértékelését, önbecsülését, amely kellö önbizalmat adhat további munkájukhoz. A portfólió a tanár-tanuló közös munká- 
ján alapuló személyes dokumentum, egyéni tanulási utat nyithat meg. A portfóliónak van tárgyiasult eredménye, ami büszkeséggel tölti el a hallgatókat, a portfólió alkalmazása során az összegyüjtött és felsorakoztatott dokumentumok segítségével láthatóvá válik a fejlödésük. Tapasztalatunk, hogy a módszer egyértelmü önállóság növelö hatású, hisz a portfólió munka alapja az önálló hallgatói munka, rengeteg olyan helyzetet produkál, ahol egyedül kell dönteni, egyéni értékelést és véleményt formálni. Megrajzolja a kompetenciák fejlődésének útját és tudatosítja is azt. Segít feltárni készítỏjének erősségeit és gyengéit, hiányosságait a portfolióban mellékelt anyagok meggyőző erejével. A portfólió egyéni tanulási utat nyithat meg. A tanulási folyamatra helyezi a nagyobb hangsúlyt, nem a tényanyag ismeretére. A portfóliót alkalmazva a tanár szerepe is megváltozik, más óravezetést igényel alkalmazása, ez a pedagógiában paradigmaváltáshoz vezethet. Kellő tanári támogatás segítségével szervezettebbé, tudatosabbá válhat a tanulási tevékenység. Egyértelmüen hasznos a hallgatók számára, ezért feltétlenül helyet kell kapnia a tanulási és értékelési módszerek között. A portfólió alkalmazása nem zárja ki más hagyományos tanulási, ellenőrzési és értékelési módszerek lehetőségeit a képzésben, hanem bővíti azokat.

Az Eszterházy Károly Föiskolán elkészült portfóliók nyomtatott és elektronikus változatban, valamint a prezentálásnál felhasznált diák megtekinthetők az EKF Regionális Pedagógiai Kutatóközpontjában.

\section{Irodalom}

Andexer, H. - Thonhauser, J. (2001): Portfolio in der Lehrer(inen)ausbildung: Begriff, Erwartungen. Journal für Lehrerinen und Lehrerbildung, Nr. 4. 53-60.

Barret, H. (2002): Create Your Electronic Portfolio: Using off the Shelf Software to Showcase Your Own and Your student Work. 30.12.

Barton, J - Collis, A. (1993): Portfolios in Teacher Education. Journal of Teacher Education, Nr. 3. 200-210.

Behrens, M. (2001): Portfolios in der Lehrerinnenbildung. Journal für Lehrerinen und Lehrerbildung, Nr. 1. 8-16.

Falus Iván - Kimmel Magdolna (2003): A portfolió. Gondolat Kiadói Kör - ELTE BTK, Budapest.

Falus Iván - Ollé János (2000): Statisztikai módszerek pedagógusok számára. Okker Kiadó, Budapest.

Gál Sándor - Keresztény István (2006): A portfolió lehetőségei a biológia szakos tanárképzésben. EKF Tudományos Közleményei, ACTA Líceum Kiadó, Eger.

Hascher, T. - Schratz, M. (2001): Portfolios in der Lehrer(inen)ausbildung. Journal für Lehrerinen und Lehrerbildung, Nr. 1. 4-7.

Inglin, O. (2006): Rahmenbedingungen und Modelle der Portfolioarbeit. In: Brunner, Ilse; Häcker, Thomas; Winter, Felix (Hrsg): Das Handbuch Portfolioarbeit. Klett Kallmeyer Friedrich Kiadó, Deutschland. 
Kunz, H. D. (2001): Auf dem Weg zu theoriebezogenen Metakognitionen üben die eigene Unterrichtserfahrung. Journal für Lehrerinen und Lehrerbildung, Nr. 1. 44-52.

Niggli, A (2001): Portfolios und der Teorie-Praxis-Bezug im Umgang mit Ausbildungsstandards. Journal für Lehreninnen- und Lehrerbildung, Nr. 4. 26-3.

Schratz, M. - Tschegg, K. (2001): Das Portfolio im Kontiniuum unterschidlicher Phasen der Lehrerbildung. Journal für Lehreninnen- und Lehrerbildung, Nr. 4. 17-25.

Wild, J. (1997): Fachübergreifende Schlüsselqualifikationen - Leitmotiv oder Studienreform? Welbers, U.: Das Integrierte Handlungskonzept, Studienreform Aktionsformen für die Verbesserung der Lehre an Hochschulen. Luchterhand, Neuwied - Kriftel Berlin, 198-213. 